\title{
Philosophical Thought in Education as an Approach across Disciplines in All Natures of Knowledge
}

\author{
Aminuddin Hassan ${ }^{1}$, Norhasni Zainal Abiddin ${ }^{1} \&$ Sim Kuan Yew ${ }^{1}$ \\ ${ }^{1}$ Faculty of Educational Studies, Universiti Putra Malaysia, Selangor, Malaysia \\ Correspondence: Norhasni Zainal Abiddin, Faculty of Educational Studies, Universiti Putra Malaysia, 43400 \\ UPM Serdang, Selangor, Malaysia. E-mail: nonie@putra.upm.edu.my
}

Received: August 28, 2013

doi:10.5539/jedp.v3n2p168
Accepted: September 29, 2013

Online Published: October 14, 2013

\begin{abstract}
It is important to understand the concept of philosophical thought within all natures of knowledge well. This writing attempts to explore the perspective of the philosophy of education in Home Economics subjects. As with any other educational disciplines, the subject of Home Economics which is a part of the curriculum in Malaysia have a clear direction and strategy in realizing the nation's desire to produce balanced and highly skilled human resources. Home Economics is not a trashy subject to be underestimated because, ironically, it supports the philosophy and ideals towards the nation's ambition. Without philosophy, there is no path that can be used as a guide to strengthen the actions and direction of educational philosophy. Without that support, the struggle of technical and vocational education cannot provide an impact on the industry and accomplish the aspirations of the nation as a whole. From the perspective of philosophy, the arguments in explaining the importance of knowledge of Home Economics will also be discussed in this paper.
\end{abstract}

Keywords: philosophical thought, education, home economics, technical and vocational education

\section{Introduction}

Philosophy is usually associated with abstract and complicated matters. In, reality this is often not the case. In fact, anyone can think philosophically in all matters. We often philosophize unconsciously in our daily lives. Humans are curious and inquisitive, and this nature is fundamental to the basic concept of philosophy. However, it must be stressed that there is a difference between a common individual and a philosopher. A philosopher argues based on deeper thoughts with the use of the philosophical approach. A philosopher is also known as a person who describes the knowledge behind the creation of the universe around him/her, in order to study reality and truth within (Choong Keow Lean, 2008).

Knowledge on philosophy has existed for centuries. It has been developed since the era of the Greeks. Great philosophers who were famous during that time were Plato and Aristotle. Philosophy, which means 'love of wisdom', refers to the effort or approach used to investigate certain issues. Consequently, the truth will be revealed based on the perspective and scope of human thought itself. Hence, it is the base or the core of all knowledge. In other words, philosophy is a mind process based on operations conducted systematically for the purpose to seek the truth and to acquire new knowledge (Tajul, 1993).

Philosophy is easily linked to education. This is because human characters and attitude needs to be shaped based on the philosophy outlined through education system. Education is perceived as an ongoing effort that is practical in generating a change on one's attitude and behavior. Education also acts as the influential agent to encourage positive behavioral change (Mak Soon Sang, 2004). Rosnani Hashim (2003) identifies that education, from the perspective of philosophy, involves the knowledge towards individuals' attitude (metaphysics), theory of knowledge (epistemology), value (ethics) and effective methods (logic). The educational process is closely related to three aspects, namely student, knowledge and teacher. According to John Dewey, one of the Western educational figures, education is a process that focuses on enhancing human life for a better future, whereas school is the social institution that is specified in providing the needs of an individual (student). Education has to be developed with a strong foundation and the educational institution play an important role, in responding to educate, as well as to enhance the necessary values and qualities of human life. Without education, the objective of developing great nations and educated citizens would most likely fail. 


\section{The Malaysian Educational Context}

In the educational context of Malaysia, the educational system is developed to strive for unity among its people, produce human capital, and supply skilled labor in various fields as the core of national development. In accordance with the ambition to become a developed nation by the year 2020, Malaysia also emphasizes on the development of human capital, as one of the major concerns towards the success of a nation's development process. It refers to the challenges in developing the next generation's capacity and capability in all aspects of cognitive development which encompasses the elements of thought, affect (attitude element) and psychomotor (Mohd Kamil and Rahimin Affandi, 2009). Transformation in education has begun stage by stage to reset previous society's mentality, which is the sole concern on academic achievement in evaluating the ability and potential of an individual.

The current situation of education emphasizes more on academic achievement and school standards. This causes schools to focus on students' performance in academics to upgrade the reputation of the school. Consequently, educators tend to focus more on intellectual development and only teach student mainly to finish the given syllabus. Moreover, it creates a scenario where the students see learning as only a process of passing examination with flying colors. To make matters worse, higher educational institutions have now become "factories" for generating skilled labors instead of producing holistic graduates with high moral standards.

Character building in human capital development has been neglected even though it is an important. Neglect in this area causes imbalance between social development and development of modernity and is taking its toll on the national progress today. The critical issues on social problems nowadays can be seen at the same time the nation is moving forward and making progress in various areas of expertise. Undeniably, education is an important tool in building a competitive country, in order to update itself with the current development. However, educational development also needs to be parallel with the development of other aspects, such as morality and spirituality in the society.

\section{The Concept of Educational Philosophy}

Philosophy is a branch of knowledge which cannot be classified in any field of knowledge, regardless of science or religion, but it exists in all areas of knowledge as the core element (Russell, 1959). Thus, it also exists in education. Philosophical questions are sought to link as many arguments, facts or data underlying the principles and doubts of an issue. Finally, all aspects of certain issues that have been considered and examined as a whole will be revealed. In education, educators are encouraged to act in a comprehensive manner with a variety of strategies to detect a student's ability. Indirectly, all the talents and potential in students will be discovered and molded to the fullest.

Philosophers also use the speculative approach to predict something systematically and rationally, based on the current happenings or situation. Therefore, education using al-Quran and as-Sunnah as a source is an ideal principle in finding and discovering issues. Hence, it should be emphasized. From the perspective of epistemology, philosophy and theory of education are also guided by revelation of source, besides inspiration from the rational use of intellect, experience, observation, authority and inspiration (Rosnani Hashim). This view is reflected by the approaches used in education system of Malaysia. It also emphasizes on Islamic Education and Moral Education, as well as forming important elements of the National Education Philosophy.

In addition, philosophy also possesses reflective characteristics which use methods that require one to explore and think deeply and earnestly to get the answer to a question. Reflective method enables the production of comprehensive views and makes a full assessment of the accuracy. This philosophical approach has been practiced in education, particularly in resolving issues that arise in the classroom. A teacher can also be regarded as a thinker and researcher, as he/she always reflects on teaching and learning process that is performed, by raising the question of cause and effect based on the matter that was viewed comprehensively. It is necessary to improve teaching performance and ensure that the objectives of education were achieved. In regards to the role of educator as a reflective practitioner, an educator is able to diagnose students' performance and problems correctly (Mohd Sahandri et al., 2010). A teacher can perform this action by recording a reflection of teaching and learning as they complete their lessons in class.

Furthermore, the philosophy of the prescriptive approach is to put a value on a par or standard forms of behavior (ethics), as well as art value (aesthetics). Using this standard, a behavior, whether it is good or bad and right or wrong can be identified and evaluated. Various theories in education for the implementation also use a similar approach, which includes the theory of human knowledge and methods to make the process of knowledge construction effective. For example, each school will set specific rules that must be followed by each member of the school community to develop discipline, self-esteem and character among students. 
In contrast to the theory of science using scientific and descriptive approach, the approach practiced by philosophy is non-empirical. Philosophy is not based on an appreciation of thought that stresses on the physical form and facts alone, but rather, it is a thought process that requires understanding and commitment to seek the truth behind a given fact. With the existence of philosophy in every source of knowledge, the goal of education is not only directed to the formation of skill in a particular field, but also to create a human in the real sense.

In Malaysia, the educational system is supported by the National Philosophy of Education, which is used as a reference at all levels of education, including primary education, secondary education and higher levels. Development of education in the context of human capital is dependent on the government's intention to produce a generation that is comprehensive and balanced, with holistic development in the physical, emotional, spiritual and intellectual aspects which are entirely centered on the belief and devotion to God.

\section{The Areas in Education}

In general, education can be classified into three areas, namely sciences, social sciences and the arts. Science Education covers knowledge, such as science and technology, mathematics, engineering and its branches. Science education teaches modern science and the scientific approach in studying environmental research. The social sciences include economics, language, communication, philosophy, psychology, sociology, and others associated with the study of humanity and the phenomenon that occur in the society or specific communities. The arts are usually referring to the visual arts, such as photography, painting, sculpture, fine arts (e.g., music and theater), and the latest, multimedia (that is approach of arts which benefited by the use of technology).

The areas of knowledge are increasingly showing its development, in line with the advancement of research and exploration of knowledge, which results in a variety of new knowledge emerge. In regards to the wide availability of education all over the world, the goal of education remains the same, which is to deliver knowledge and teach universal values of human civilization in order to strive for excellence (Lean Choong Keow, 2008).

\section{The Development of Technical and Vocational Education (TVE)}

Philosophy exists behind every field of knowledge and its development. The same goes to the Technical and Vocational Education (TVE). The field of TVE is important and appropriate as a model for the purpose of analyzing the significance of philosophical approach. This field was chosen as the subject of writing in this paper to clarify its position and relevance when it is often placed as second class in the world of education.

TVE began many years ago, during the time where societies were largely dependent on life skills. The knowledge is acquired through informal education, i.e., passed down from one generation to another generation. Some of the examples of life skills are farming or gardening, planting, timber and metal trades, kitchen's work and making crafts. In fact, the vocational education has received attention and concern from the government through the Rahman Talib Report in 1960 and the Education Act 1961. During that time, the government has begun shaping strategies and started to focus on vocational and technical education to meet the requirements of skilled manpower in the country. TVE is now available in formal education and training that provides individuals with not only academic knowledge, but also technical skills. Moreover, it is implemented in the education system in this country, starting from the lowest level (basic life skills), secondary (optional technical and vocational), to higher learning levels.

As the country was in post-modernization era, to some extent, it is seen as an opportunity to elevate the field of vocational training into the society. It is supported by the fact that the current economic situation depends on professionals and highly skilled workforce to achieve the nation's dream to build a developed country. These changes have made TVE one of the main agendas in national development, particularly in achieving a national consensus expressed in Vision 2020, which is to become an industrialized nation and achieve the aim to be a developed country. Focusing on producing competent and skilled individuals in a given area has been the catalyst in the improvement of existing education system to upgrade and increase the human resources related to technical and vocational field.

\section{Field of Home Economics}

In regards to the field of TVE in philosophy described above, each discipline of TVE also contains its own philosophy. Home Economics has been included as one of the subjects in the context of school education curriculum in Malaysia. The importance of this subject will be described in terms of philosophy. Home Economics subjects were selected based on the perspective that it is equipped with the essence to represent the national education philosophy and had potential to grow as well as to produce students who are competent in the professional world later. 
Home Economics was introduced under the Technical and Vocational Education program as an effort to improve the quality of education in this country. The main purpose of this subject is to produce individuals who are independent, skilled, noble, responsible and acutely aware of technological development and current economic trends (Ministry of Education, 2002). It is consistent with the National Philosophy of Education which focuses on holistic instead of selective individual development. Home Economics is an elective subject offered in secondary schools in the Integrated Curriculum for Secondary Schools (ICSS). The curriculum in the subject is a continuation of Life Skills taught in primary and lower secondary schools - a discipline that emphasizes on the knowledge and skills in the use of resources to improve the quality of life. As its name suggests, these life skills are important for character building and skills training of individuals. Furthermore, it is also important as there are elements of additional value that can be used to guide and balance an individual's life.

By examining the field of TVE from the standpoint of Western philosophy, it shows a pragmatism approach where it emphasizes on knowledge that can be practiced in daily life (Rojewski, 2002). John Dewey, who is one of the leading theorists, has stated that the main goal of education is to meet the needs and demands to face challenges in life. This educational philosophy stressed on active learning methods, where teachers will provide experience so that students can learn by doing. Thus, TVE is in line with the theory, because students will be guided to experience meaningful things that are based on the context of the curriculum itself. Home Economics in the field of vocational aspect is capable of preparing students to enter a wide range of fields such as in food, textiles, science and design. According to Kneller, a subject is arranged with the aims to prepare students for a job. As a matter of fact, the subject of Home Economics provides students with knowledge and skills about food, science, nutrition, art of cooking, clothes and sewing.

In the Western perspective, it seems as though there are flaws in the system of TVE itself, which is more geared to prepare students to specialize in certain fields only. However, if TVE is studied and adapted in the context of the Malaysian education system, the philosophy held by TVE is in line with the National Education Philosophy. NEP stresses that the goal of education is not merely to establish an individual's disposition through the field given, but more importantly, to develop the individual's potential comprehensively and holistically. Home Economics should not be seen as only a platform to generate human resources; the implicit knowledge of the element behind it should also be emphasized. This is to enable students to understand the concept and appreciate the value of knowledge itself, thus producing more quality scholars in this area.

In the past, the concept of home economics is often defined as the appropriate subjects that are taught to women to provide them with the knowledge associated with household chores, such as cooking and sewing. Today, this perception has begun to change. In the perspective of science, Home Economics is a field with innovation and application of science and technology to improve the quality of everyday life. Technology implemented in the field of learning Home Economics allows students to be exposed to the current developments, as well as to use their skill in the existing technology. In addition to producing students who are aware of the current trend of technology usage, it is also useful in shaping the human character to become more independent, creative, initiative and confident to face the reality of life (Yeo Kee Jiar \& Zulkarnain, 2010). In addition, knowledge and understanding about food and food-related issues is necessary for personal and family health. It allows individuals to apply this knowledge into practice in daily life, which also benefits widely in the family, society and food industry. Indirectly, it will improve the quality and health condition through proper eating habits, and thus, this leads to a more prosperous and harmonious family and society. However, all of these things will not be attained, if students themselves do not value and appreciate the knowledge that they had gained. Anyway, it is an important aspect of spirituality applied to their inner thought that arise the sense of responsibility for the knowledge they acquired. As the saying goes, "Knowledge without practices is like trees without fruit, they are only good to see but do not bring benefits to all."

Much can be explored on subject of the Home Economics philosophy through the Islamic perspective. Muslims are very concerned about education and they rank education highly among its followers who are eager to seek for knowledge. This is because proper leveraging of knowledge and skills can contribute to the development of economic and social aspect. In Islam, knowledge is broad because a person is encouraged to research and investigate the nature to acquire knowledge. Education in Islam does not separate the world with religion. In fact, it is in line in order to provide a perfect mastery of knowledge. Similar with the case of Home Economics subjects, individuals should not restrict their thinking or perception that the subjects is learnt only to pass examinations and obtain the best employment after completing their studies. Appreciation of knowledge will not seep into the soul of a person if the knowledge is learned only in the world life's interest. In fact, it is like to learn something in vain without getting the blessing from the Creator. 
A holistic approach should be practiced by integrating all the dimensions in nourishing the development of human knowledge, including the development of intellect and mind, skills and character building (Mohd Jilani, 2009). This is because these things are elements that can be digested to produce individuals who are committed to properly play their roles as caliphs of God in this world. Referring back to the National Education Philosophy, balanced human beings are individuals who are well-developed in terms of intellectual, spiritual, emotional and physical aspects, all of which are on the same platform that is centered on belief in and devotion to God. Based on this educational philosophy, it should be used as a guide for the educators in the selection of effective learning activities, development programs and selection of beneficial programs that lead towards successful educational process in this country.

Similar to the approach used in other curriculum, intrinsic values are also embedded in the subject of Home Economics. Practice on these values can be attributed to universal values, and moreover, to inculcate good values in the personal formation. For example, awareness of the importance of providing clean and safe food to customers is based not only on profit-driven factors alone, but also on a sense of responsibility that should be taken when an individual is involved in the field of food and beverage business and entrepreneurship in future. Similarly, regarding the question of permissible and prohibited in food production, if food producers and entrepreneurs were enlightened and educated on the precise value of the trust, within the status of race and religion, there will be no incidents of fraud related to these issues. These values need to be nurtured from the school directly or indirectly, so that it can be used as a basis for the formation of good manners. With the subject of Home Economics, philosophy and skills contained in it can be integrated, where students are given opportunities to pursue their passions, and thus, expand the potential and skills that exist in them for the benefit of society. This is also one of the main pillars in the National Philosophy of Education statement.

\subsection{Educational Goals of Home Economics Subject}

The subject of Home Economics nurtures the understanding and skills to improve the quality of life for individuals, families and communities. Emphasis is given to the mastery of skills, particularly through exploration in the field of food and nutrition, clothing, residence, family and community life. In the process of teaching and learning Home Economics, the inculcation of values and approach Critical and Creative Thinking Skills (KBKK) are stressed, in order to produce a balanced and harmonious individual. Continuous exposure in the field of business and entrepreneurship can cultivate flexibility and adaptability within students and getting them ready for a consumer-oriented society and to practice positive work culture. Mastery of these subjects also aims for students to identify and apply knowledge and skills, in order to increase their adaptability in changing situations of modern life. Home Economics education trains student to be able to comply with comprehensive technology and development, accounting mindset, attitude and practices responsible for providing an optimal and effective contribution to community development (Ekonomi Rumahtangga Syllabus, 2003). Goals, particularly in the field of Home Economics and TVE, can generally be explained again by a statement taken from Azizi Yahaya \& Gangaoury (2010). The statement reads:

"Education and training will also be developed and enhanced not only to provide individuals with the appropriate knowledge and skills but also to produce responsible citizens and have strong moral and ethical values. In addition, these programs will help create a workforce that has the technical capabilities that will enhance Malaysia's economic competitiveness." (Government of Malaysia, 1991).

\subsection{Aspirations of Students' Achievement in the Field of Home Economics}

An educational program will not be established without its own clear philosophy, goals and principles. For Home Economics, aspects of the acquisition of practical knowledge and experience that can be accessed by students are important. Aspects of life skills are key elements in shaping the direction and identity of the TVE and the field under the subject. Home Economics is an applied subject combining theory with practice that contains useful skills, so that the students can act and conduct productive daily life, in line with current technology needs (Yeo Kee Jiar and Zulkarnain, 2010). Learning these skills is clearly to enhance cognitive skills, psychomotor and affective integration, as well as a catalyst in enhancing students' confidence and willingness to venture into specific fields of work. Every person is different and is born with respective behaviors and abilities. Based on this fact, the vocational stream is also seen as a platform for students who do not perform as expected in the academic field to develop their talents and potentials in the field based on skills. This is to enable students who are facing such a situation do not remiss in fulfilling demands in this advanced era. Without high achievements in academic performance, these skills remain useful to cope with this challenging life. Furthermore, the home economic discipline can help students to become all-rounded because it is one subject that incorporates many topics of interest and disciplines that will lead individuals to the fields of nutrition, hospitality management, design and textiles industries, etc. 
In addition to providing students with life skills, Home Economics also provides space for students to develop their thinking skills. The emphasis of learning does not only apply in theory, but also in hands-on practices that encourage students to think critically and creatively. Learning as they go through this training and experience will expose and increase students' innovative and creative capacity, particularly in terms of the concept of invention and entrepreneurship. These learning experiences in Home Economics also develop flexibility and adaptability in students. It is in line with the National Education Philosophy to enhance the intellectual capabilities of students with application of critical thinking skills and creativity. This aspect is important to encourage students to generate ideas and new thinking, so that they do not need to rely on one source of knowledge only.

Besides that, skill-based subjects also promote the development of generic skills component which can be applied in communication skills, teamwork, problem-solving skills and interpersonal skills (Noraini \& Pemalatha, 2004). Thus, the curriculum for TVE subjects emphasizes on the application of communication skills so that students learn to be versatile. Home Economic field becomes an example for this purpose, and brings major implications in labors' production that is compromised with industry demands. All of these are seen as noble efforts in an integrated manner that will foster the development of the nature and character of students to become more independent, capable and competent to adapt the living environment and working environment in the future.

\section{Conclusion}

An ideal educational atmosphere - good and balanced, is built from the system that is based on philosophy, religion, culture and identity of society itself. Home Economics is a part of the education curriculum in Malaysia that has a clear direction and strategy in realizing the nation's desire to produce balanced and highly skilled human resources. A field based on practical and life skills is an important aspect of students' life balance. With exposure to the practical aspects of life skills from the lower level, it is expected to provide experience and learning that do not only focus on theoretical knowledge, but also encourage the aspects of practice that can help to develop the physical potential of students through the usage of a variety of equipment, applying a tendency in thinking skills, strengthening the spiritual and emotional stability through the building of the generic skills.

\section{References}

Azizi, Y., \& Gangaoury, C. (2010). Kemahiran Hidup. Kemahiran Hidup. (Unpublished)

Choong, L. K. (2008). Falsafah dan Pendidikan di Malaysia. Selangor: Kumpulan Budiman Sdn. Bhd.

Kementerian, P. M. (1990). Falsafah Pendidikan Negara. Kuala Lumpur : Dewan Bahasa dan Pustaka.

Kerajaan, M. (1991). Rancangan Jangka Panjang Kedua, 1991-2000 (RRJP22). Kuala Lumpur. Percetakan Kerajaan.

Mak, S. S. (2004). Ilmu Pendidikan untuk KPLI ( Edisi ketiga). Kuala Lumpur: Kumpulan Budiman Sdn.Bhd.

Mohd, J. M. N. (2009). Menerapkan Budaya Kecemerlangan dalam Pengajaran dan Pembelajaran. Seminar Pendidikan Kejuruteraan, 54-62.

Mohd, K. A. M., \& Rahimin, A. A. R. (2009). Perubahan Sosial dan Impaknya Terhadap Pembentukan Modal Insan Menurut Ibn Khaldun. Jurnal Hadhari, 1(1), 45-76.

Mohd, S. G. H., Ramli, B., \& Shafee, M. D. (2010). Karakter Guru. Selangor: Utusan Publication \& Distributors Sdn Bhd.

Norani, M. N., \& Peremalatha, N. (2010). Penerapan Kemahiran Generik Dalam Mata Pelajaran Kemahiran Hidup Bersepadu (KHB). (Unpublished)

Pusat, P. K. (2003). Sukatan Pelajaran Mata Pelajaran Ekonomi Rumahtangga. KBSM: Kementerian Pendidikan Malaysia.

Rojewski, J. W. (2002). Preparing the Workforce of Tomorrow: A Conceptual Framework for Career and Technical Education. Journal of Vocational Education Research, 27(1), 7-35. http://dx.doi.org/10.5328/JVER27.1.7

Rosnani, H. (2004). Falsafah Penyelidikan Pendidikan dari Perspektif Islam. Jurnal Pendidikan Islam, 11(1), $1-16$.

Tajul, A. (1993). Perspektif Falsafah \& Pendidikan di Malaysia. Selangor: Dewan Bahasa dan Pustaka.

Yeo, K. J., \& Zulkarnain bin Muhammad. (2010). Hubungan Antara Harga Diri Dengan Pencapaian Mata Pelajaran Kemahiran Hidup Pelajar Sekolah Menengah. (Unpublished) 


\section{Copyrights}

Copyright for this article is retained by the author(s), with first publication rights granted to the journal.

This is an open-access article distributed under the terms and conditions of the Creative Commons Attribution license (http://creativecommons.org/licenses/by/3.0/). 